DOI: http://dx.doi.org/10.33846/hn50506

http://heanoti.com/index.php/hn

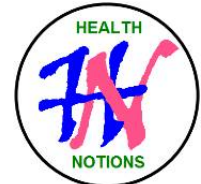

RESEARCH ARTICLE

URL of this article: http://heanoti.com/index.php/hn/article/view/hn50506

\title{
Effectiveness of Midwifery Training Update on Midwife Knowledge Improvement
} in Midwifery Services in Magetan

\author{
Nani Surtinah $^{1(\mathrm{CA})}$, Sunarto $^{2}$ \\ ${ }^{1(\mathrm{CA})}$ Department of Midwifery, Poltekkes Kemenkes Surabaya, Indonesia; nanisurtinah840@gmail.com \\ (Corresponding Author) \\ ${ }^{2}$ Department of Midwifery, Poltekkes Kemenkes Surabaya, Indonesia; sunartoyahyamuqaffi@gmail.com
}

\begin{abstract}
One of the efforts made to improve the knowledge, skills and competence of midwives is the Midwifery Update training. This study aims to determine the effectiveness of midwifery update training on increasing knowledge of midwives in midwifery services. The study design was a post-test only control group design. The population consisted of an experimental group of 41 people and a control group of 41 people. The experimental group had the midwifery update training in 2019 , while the control group was midwives who had never attended midwifery update training in 2019. The experimental group and the control group were selected by using cluster sampling technique after that the sample selection used simple random sampling. Data analysis was used independent samples $t$-test. The mean knowledge results of the midwifery update group that had never attended midwifery update training was 55.11, while the mean knowledge results of the midwifery update group knowledge was 75.19. Based on the independent t-test, it was found that the t-count results were $-8,987$ with a p-value of $0.000(<0.05)$, so there was a difference of knowledge between midwives who had not attended training and had attended training. As the conclusion, the midwifery update training is effective in increasing the knowledge of midwives so that midwives are required to take part in the midwifery update training.
\end{abstract}

Keywords: training; midwifery update; knowledge

\section{INTRODUCTION}

\section{Background}

Midwives as one of the strategic health workers who have the task and function of providing midwifery services to improve the health status of mothers and children, especially women's reproductive health and the growth of infants and toddlers. Many experts have proven that improving maternal and child health status in preparing a quality generation begins early, i.e. from before pregnancy or even starting from adolescence in accordance with the women's reproductive health cycle. Supervision of the health of the mother before becoming pregnant is very determined the quality of the child to be born. Likewise, supervision of pregnancy and birth preparation and ready to be a parent is a very important part of a midwife's attention. In addition, midwives as female partners and become role models for families, therefore the readiness of midwives to provide quality midwifery services, becomes a fundamental need. In addition, in providing public health services, midwives must comply with applicable laws and regulations ${ }^{(1)}$.

One of the implementations that can be done to overcome the problem requires a breakthrough in the form of Midwifery Update (MU) training that aims to maintain quality and improve the knowledge, skills and competence of midwives so as to provide quality services to the health of mothers, infants, toddlers and reproductive health including Family Planning services. The training is packed using more interactive methods. After being given training, it is expected that the knowledge and skills of midwives in Magetan in providing midwifery services will increase.

This study aims to find out the effectiveness of midwifery training update on improving midwife knowledge in midwifery services in Magetan. 


\section{METHODS}

This research used a quasi-method of experimentation. The research design chosen was post-test only control group design which aimed to find out the effectiveness of Midwifery Update training on improving midwife knowledge in midwifery services in Magetan, which was comparing posttest results to determine the effectiveness of treatment. In this design both the experimental group and the control group were compared. The experimental group that received treatment was attending Midwifery Update training while the control group did not get treatment. The location of this research was The Association of Indonesian Midwives, Magetan Branch. Research time starting from the preparation of proposals, data collection of research until the exam was January to December 2020.

The population in this study was all midwives in The Association of Indonesian Midwives, Magetan Branch, numbering 680 midwives. The number of midwives who participated in the training was 582 consisting of four midwifery update training clusters. In this study, the samples used two groups, one group as an experimental group and one group as a control. The experimental group in this study was members of the Association of Indonesian Midwives, Magetan Branch who participated in Midwifery Update training, while the control group was members of The Association of Indonesian Midwives, Magetan Branch who did not participate in Midwifery Update training, with a sample size of 82, consisting of 41 midwives in experimental group and 41 midwives in control group. Sample size was determined by using the Hypothesized Test of Different Proportions formula. The sample of experimental group was selected by cluster random sampling technique, while for control group was selected by simple random sampling technique.

Independent variables in this study was Midwifery Update training, while the dependent variable was knowledge in midwifery services. Data about knowledge were collected by using questionnaires. The data analysis technique used to see the effectiveness of midwifery training updates on the increased knowledge of midwives was independent samples T-test.

\section{RESULTS}

\section{Distribution of Respondent Characteristics}

The number of subjects of this study was 82 respondents consisting of 41 midwives who had attended midwifery update training and 41 midwives who had never attended midwifery update training. Characteristic respondents were classified based on age and recent education. In the treatment group, midwives who had participated in midwifery update training at most were under 35 years old at $72.5 \%$, as well as for the control group with the most under-35 is at $97.56 \%$. Respondents' last education consisted of Diploma 3 of Midwifery, Diploma 4 of Midwifery, and Master of Health. In the treatment group obtained the most recent education was Diploma 3 Midwifery, as was the control group at most $68.29 \%$ educated Diploma 3 Midwifery.

Table 1. Distribution of respondent characteristics

\begin{tabular}{|l|l|c|c|c|}
\hline No & Characteristics & Group & Frequency & Percentage \\
\hline 1 & Age & & & \\
\cline { 2 - 5 } & $<35$ years old & Treatment & 29 & 72.5 \\
\cline { 3 - 5 } & & Control & 40 & 97.56 \\
\cline { 2 - 5 } & \multirow{2}{*}{235 years old } & Treatment & 12 & 29.26 \\
\cline { 3 - 6 } & & Control & 1 & 2.43 \\
\hline \multirow{4}{*}{2} & Education & & & 90.24 \\
\cline { 2 - 5 } & Diploma Third & Treatment & 37 & 68.29 \\
\cline { 2 - 5 } & & Control & 28 & 4.87 \\
\cline { 2 - 5 } & Diploma Fourth & Treatment & 2 & 29.26 \\
\cline { 2 - 5 } & & Control & 12 & 4.87 \\
\cline { 2 - 5 } & Master of Health & Treatment & 2 & 2.43 \\
\cline { 2 - 5 } & & Control & 1 & \multicolumn{2}{c}{} \\
\hline
\end{tabular}




\section{The Distribution of Knowledge}

Based on Table 2, the mean score of knowledge of control group was 55.11, the lowest score was 31.48, the highest score was 82.85 . While the mean score of knowledge of treatment group was 75.19 , the lowest score was 60.00 , the highest score was 94.28 .

Table 2. The mean score of knowledge of control group and treatment group

\begin{tabular}{ccccccc}
\hline Group & $\mathrm{n}$ & Mean & Lower & Upper & Std.deviation & Std.error mean \\
\hline Never been training & 41 & 55.11 & 31.48 & 82.85 & 12.33 & 1.92 \\
\hline Ever training & 41 & 75.11 & 60.00 & 94.28 & 7.25 & 1.13 \\
\hline
\end{tabular}

\section{The Effectiveness of Midwifery Update Training on Improving the Knowledge of Midwives}

The normality test of data distribution using Kolmogorov-Smirnov test (Table 3) showed the p-value of 0.109 , meaning the data distribution was normal.

Table 3. The results of normality test

\begin{tabular}{cc}
\hline & Knowledge \\
\hline $\mathrm{N}$ & 82 \\
\hline Mean & 65.15 \\
\hline Std Deviation & 14.25 \\
\hline Kolmogorov-Smirnov Z & 1.207 \\
\hline Significance (2-tailed) & 0.109 \\
\hline
\end{tabular}

Table 4. The results of independent samples t-test

\begin{tabular}{|c|c|c|c|c|c|c|c|c|c|}
\hline \multirow{3}{*}{ Knowledge } & \multicolumn{2}{|c|}{$\begin{array}{l}\text { Levene's test for } \\
\text { equality of variances }\end{array}$} & \multicolumn{7}{|c|}{ t-test for equality of mean } \\
\hline & \multirow[b]{2}{*}{$\mathrm{F}$} & \multirow[b]{2}{*}{ Sig. } & \multirow[b]{2}{*}{$\mathrm{T}$} & \multirow[b]{2}{*}{ Df } & \multirow[b]{2}{*}{$\begin{array}{c}\text { Sig. } \\
\text { (2-tailed) }\end{array}$} & \multirow[b]{2}{*}{$\begin{array}{c}\text { Mean } \\
\text { Difference }\end{array}$} & \multicolumn{3}{|c|}{$95 \%$ CI of the Difference } \\
\hline & & & & & & & $\begin{array}{l}\text { Std.error } \\
\text { Difference }\end{array}$ & Lower & Upper \\
\hline $\begin{array}{l}\text { Equal variances } \\
\text { not assumed }\end{array}$ & 10.133 & 0.002 & -8.987 & 64.709 & 0.000 & -20.08 & 2.234 & -24.54 & -15.62 \\
\hline
\end{tabular}

From the results of the independent samples t-test, p-value of Levene's test was 0.002 , so the data variety of the two groups was not homogeneous. Based on the t-test, p-value was $0.000(<0.05)$, so it could be concluded that there was a difference of knowledge between treatment group and control group. Furthermore, the mean difference between the two groups was -20.08 with the difference between -24.54 and -15.62 for the confidence interval of the difference lower upper.

\section{DISCUSSION}

Law No. 36 of 2014 on Health Workers article 30 paragraph (1) and (2) mentioned that the development of health workers is directed to improve the quality and career of health workers. The development of health workers as referred to in paragraph (1) is carried out through education and training and sustainability in carrying out practices. Law No. 43 of 2009 concerning The Principles of Personnel section six of Article 31 paragraph (1) and (2), it is stated that to achieve the maximum effectiveness and effectiveness of the arrangement and implementation of education and training of civil servant positions aimed at improving service, quality, skills, abilities and skills. The next paragraph explains that the implementation of the provisions as referred to in paragraph ${ }^{(1)}$ is stipulated by a government regulation. Both laws clearly mandated that health workers, more than health workers civil servants, should attend training to update science and competence.

The results illustrated that the group of midwives who have attended midwifery training update before after being given training both grades of knowledge is significant. The results of this study support research ${ }^{(2)}$ 
which states that midwifery update training is very effective to increase the knowledge of midwives in Surakarta.

Some factors that can influence a person's knowledge so that his competence differs, among others: qualifications of education level, type of work, age, interest, experience, the culture of the surrounding environment and information ${ }^{(3)}$. Knowledge is the impression in the human mind as a result of the use of its senses. Knowledge is all that is known based on the experience gained by every human being. Individuals tend to act according to knowledge, awareness and attitudes towards stimulation.

The figure of the number of participants who scored below the group average for groups who had never attended the training was $56 \%$. The number of participants who scored below the group average for the group who had participated in the training was $46 \%$. This data provides information that the distribution of knowledge results after training is uneven. The influential factor is the recall of participants to work on test instruments. According to ${ }^{(4)}$ factors that affect a person's memory include: age, gender, disease, nutrition, disease, concentration and attention.

Although this study does not link memory factors to the effectiveness of training, it is necessary to explain the relationship of memory with the ability to recall the training program that has been given. According to ${ }^{(5)}$, an older person tends to have a decreased ability to remember compared to younger people. As we get older, brain cells will become more exhausted in carrying out their functions and cause them to not be able to work optimally as they were when they were young. Age factors can be related to cognitive function according to the study ${ }^{(6)}$. States that changes that occur in the brain due to age, among others, the function of information storage (storage) undergoes a slight change. In old age, there is death in some parts of white matter because the blood supply to the brain is not as healthy as in youth. The production of endogenous chemicals such as neurotransmitters that carry signals to the brain is also reduced by about $50 \%$. In the cellular aspect, aging results in a decrease in neuron cells in the hippocampus by $5 \%$ to $20 \%$ until the age of 80 years. Gender is thought to affect a person's memory even though there is no certainty between a man and a woman. Women are thought to be more numerous and tend to be forgetful. This is due to hormonal influences, stress that causes memory to decrease, eventually easy to forget. Estrogen receptors in women are found in areas of the brain that play a role in learning and memory functions, such as the hippocampus. Low levels of estradiol in the body have been associated with decreased general cognitive function and verbal memory ${ }^{(7)}$. Cortisol levels also affect emotions and memory, wherein women's cortisol levels are affected by the menstrual cycle. Increased cortisol levels in women gave negative relationships (decreases) in amygdala function, while in men gave positive relationships. In men increased cortisol levels were associated with stronger resting-state functional connectivity in the left amygdala with bilateral nucleus caudatus, left putamen, left and right mid-frontal gyrus, and right superior frontal gurus. While in women increased cortisol levels were associated with decreased resting state functional connectivity in the above structures ${ }^{(8)}$. Differences in knowledge, results in each subject vary depending on the concentration and attention of each subject. The training action of a number of lesson hours (JP) applied to the midwifery update training module has met the standards of improving the competence of civil servants issued by the State Administration Agency Number 10 of $2018^{\left({ }^{9}\right)}$ conducted for 30 hours of lessons (4 days). Standardization of the midwifery training update is applied nationally to meet the standardization of quality assurance and fulfillment competency achievement aspects of knowledge, skills and abilities as stipulated in this regulation.

Employee training and development can be defined as the planned efforts of the organization to improve the knowledge, skills and abilities of employees. Training and development are two of the same concepts, namely to improve knowledge, skills and abilities. But when viewed from the objectives, training is emphasized more on improving the ability to do specific work at this time, and development is emphasized more on increasing knowledge to do the work in the future, which is done through an integrated approach with other activities to change work behavior.

Competence is one of the principles that become the basis in the profession of government employees. It is as stated in Law No. 5 of 2014 article 3 which states that government employees as a profession is based on the principle of one of which is the necessary competencies in accordance with the field of duty. Furthermore, according to article 69, competence is also the basis in the career development of government employees. One of the competencies in question is technical competencies measured from the level and specialization of education, functional technical training, and technical work experience.

Choice of midwife development model through midwifery training activities update this time using Action-based Learning model. This training model is carried out continuously by referring to solving real problems encountered in the field. Participants were explained about the concept while solving real problems (learning by doing principle). There are several advantages with training and development for midwives that will eventually also bring benefits to institutions with this model including: encouraging the achievement of midwife self-development, providing opportunities for midwives to develop and have a view of the future of their careers, helping midwives in dealing with conflicts and tensions, increasing job satisfaction and work 
achievement, becoming a way to improve skills in socializing and communicating, help eliminate fear in trying new things in her work, and be able to move midwives to achieve institutional goals ${ }^{(10)}$.

Based on the consideration of the benefits that can be obtained from the training activities above, the midwifery training update has a good impact on the performance of these employees as individuals. This will obviously bring improvements to the performance of the organization if training and employee development is carried out in a planned and sustainable manner. Therefore, further evaluation of the results of this study is required whether the behavior midwives post-training is better or remains the same even decreased by including variables that affect performance including individual perception factors towards the organization and organizational commitment in the development of midwife careers ${ }^{(11)}$.

The test instrument used to measure the knowledge of midwives or trainees is a written test in the form of multiple-choice questions. Written test using the posttest method. This method is a highly recommended assessment tool to measure the success of the progress of a learning process because the evaluation is concise and effective. Assessment of the ability of training participants post-test is given after the provision of training materials with the aim to know where the respondent's understanding of the training material after the activity is carried out ${ }^{(12)}$.

There is a difference in the results of knowledge after midwifery training update between the group of midwives who have never attended the training and have attended midwifery update training. The group of midwives who had previously been given similar training had better knowledge results compared to the group of midwives who had never received similar training. So, midwifery training updates are effective to increase midwives' knowledge about midwifery services. The picture of the results of this research supports previous research that the functional competency trainings of midwives can improve the knowledge and skills of midwives so that services to the community are better ${ }^{(13)}$.

The role of midwife works between village midwives, coordinator midwives and midwives at health centers, hospitals and clinics varies greatly. But functionally the role of midwives in providing services to the community depends on their qualifications. The role of a diploma graduate midwife is certainly different from that of a graduate midwife. So, the type of training needed is adjusted to the qualifications of midwives in each institution. All trainees/midwives report that they still need another competency training. The facility must provide facilities including funding for the development of midwife competencies. Therefore, further evaluation of the results of this study is required whether the behavior midwives post-training is better or remains the same even decreased by including variables that affect performance including individual perception factors towards the organization and organizational commitment in the career development of midwives ${ }^{(11)}$.

\section{CONCLUSION}

Based on the results of research and discussion, the conclusion of this study is that the training of midwifery update is very effective in increasing the skills knowledge and competence of midwives.

Further evaluation of the results of this study is needed, whether the behavior of post-training midwives is better or remains the same even decreased by conducting surveys or follow-up research by including variables that affect performance including individual perception factors towards the organization and organizational commitment in the development of midwives' careers. Recommendations to the Indonesian Midwives Association to require its members to attend midwifery update training.

\section{REFERENCES}

1. Dinkes Kab. Magetan. Profil Kesehatan Kabupaten Magetan tahun 2017. Magetan: Dinkes Kab. Magetan; 2018.

2. Fitriyya M. Efektifitas Pelatihan Midwifery Update terhadap Peningkatan Pengetahuan Bidan pada Pelayanan Kebidanan di Surakarta. PROFESI Media Publikasi Penelitian. 2018;15(2):112-116.

3. Sartika D, Kusumaningrum M, Aziza TN, Luthfie W, Amrullah R, Hidayah KL. Pengembangan Kompetensi Aparatur Sipil Negara. Darto M, Mariani W, Eds. Samarinda: PKP2A III LAN Samarinda; 2016.

4. Frydenberg M, Andone D. Learning for 21 st Century Skills. 2011;314-318.

5. Demetry C. Work in progress - An innovation merging classroom flipll and team-based learning. In Frontiers in Education Conference (FIE). 2010.

6. Ling JJC. Psikologi Kognitif. Surabaya: Airlangga; 2012.

7. Reed SK. Kognisi Teori dan Aplikasi. Jakarta: Salemba Humanika; 2011.

8. Hall JE. Guyton and Hall Textbook of Medical Physiology. Philadelphia: Elsevier Inc.; 2016.

9. LAN. Peraturan Lembaga Administrasi Negara Republik Indonesia Nomor 10 tahun 2018 Tentang Pengembangan Kompetensi Pegawai Negeri Sipil. Jakarta: LAN; 2018. 
10. Ella S, Andari RN, Krismiyati, Wahyuadianto A, Amalia S. Pedoman Umum Pengembangan Kompetensi Teknis Jabatan Fungsional di Instansi Pemerintah. Zulfikar, Ed. Jatinangor, Sumedang: Pusat Kajian dan Diklat Aparatur I LAN; 2018.

11. Tjahyono A, Christanto CV. Analisa Pengaruh Perceived Organizational Support Terhadap Komitmen Afektif, Komitmen Normatif dan Komitmen Berkelanjutan pada Karyawan di Hotel X. Surabaya; 2016.

12. Kirkpatrick DL, Kirkpatrick JD. Implementing the Four Levels; A Practical Guide for Effective Evaluation of Training Programs. San Fransisco: Bernnet-Koehler Publisher Inc.; 2007.

13. Usnawati N, Prasetyo D, Setiawati EP, Husin F, Rusmil K, Dhamayanti M. Pengaruh Pelatihan Safe Injection terhadap Peningkatan Pengetahuan, Sikap dan Ketrampilan Bidan Desa dalam Pelaksanaan Imunisasi di Kabupaten Magetan. IJEMC. 2014;1(1):67-77. 